\title{
Kudumbashree as a Catalyst for Economic Empowerment of Rural Women through Self Help Groups in Kerala
}

\author{
Dr. Mohd Asif Khan ${ }^{1}$, Nisha.K.M ${ }^{2}$ \\ ${ }^{1}$ (Associate Professor, Department of Commerce, Aligarh Muslim University (AMU), India) \\ ${ }^{2}$ (Research Scholar, Department of Commerce, AMU, India)
}

\begin{abstract}
The Empowerment of women in economic, social and political settings has become one of the most important concerns of modern and elite world of $21^{\text {st }}$ century. The organisation of Self Help Groups (SHGs) constitutes a widely accepted development strategy for women empowerment and poverty alleviation. The present paper focuses on the role of Kudumbashree (KDMS) in women's economic empowerment through SHGs in Kerala. It is one of the largest women's movement in Asia having over 37 lakh members covering more than 50 percent of households in Kerala. The broad objectives of the study is to examine the demographic profile of the KDMS members, to identify the effect of the various demographic variables on economic empowerment of KDMS members for the sub samples based on age, marital status, educational level and occupation. The study is mainly based on primary data from $150 \mathrm{KDMS}$ members collected through interviews and meetings. Secondary data from research studies, annual reports, websites etc of government and non-governmental organisations were also used. Data collected was carried out by using structured interview schedule and data analysis done through applying ANOVA as the main statistical technique, using SPSS software. The demographic profile of Neighbourhood Groups (NHG) members selected as sample reveals that majority of the members in KDMS are married and most of them belong to the age group of 31 to 45 years. It was found that there is economic empowerment among the members with respect to certain demographic variables. Statistical significance in the inter group differences between the various categories of demographic variables and economic empowerment in general and with respect to certain specific economic parameters were also identified. KDMS acts as a catalyst for economic empowerment of women by providing economic security, social solidarity and political betterment of women of the particular region.
\end{abstract}

Keywords: Women Empowerment, Kudumbashree (KDMS), Self Help Groups (SHGs), Neighbourhood Groups (NHGs), Economic Empowerment.

\section{Introduction}

The Empowerment of women in economic, social and political arena has become one of the most important concerns of $21^{\text {st }}$ century. It is central to the issue of equality, justice and liberation in the country. Women constitute almost half of the world's population, but are the most deprived and unproductive members in the economy of many world nations. Promoting various income generating activities especially among rural women is perceived as one of the most powerful medium to resolve several socio-economic and even political problems. Empowerment is a process of awareness and capacity building, leading to a greater participation and greater decision making power. The process of empowerment strengthens ones innate abilities through acquiring knowledge, power and experience Murugan and Dharmalingam (2000) [1]. Accordingly, empowerment refers to acquiring the ability and capacity to make strategic life choices in an environment at individual, group or societal levels which were previously denied or not available. When it occurs at individual or personal level, it will have an impact on the group and societal levels. Empowerment can thus be seen as interconnected and mutually reinforcing phenomenon that brings growth and development in various walks of life of an individual and society at large.

Women empowerment in general and poor women in particular, is the thrust area of development initiatives in India today. Empowerment of women is a process whereby women are able to organise themselves in community based participatory groups to increase their own self confidence, self reliance, assert their independent rights, counter and challenge the disparities and barriers against them, make prudent choices and also control resources which will assist in challenging and eliminating their subordination thereby bringing a beneficial social economic change. Women who have acquired better knowledge, skill and experiences and who are conscious or are sensitised of their rights and duties are empowered to a greater extent. They can build up the capacity to become economically self reliant and self sufficient, have the ability to make better decisions in their family, improve their familial and societal status and enjoy better living standards.

\subsection{Need and Significance of the Study}


Even after rapid developments taking place throughout the world, women in our country, especially in the rural areas are always denied their due role in the socio economic life of the society and still remains the victims of neglect and discrimination. Till recently many of the actions taken in favour of women are mostly welfare oriented ones rather than development oriented, and no constructive steps are taken for making women economically independent and socially vibrant. Women should be provided with the opportunities to participate in financial activities and expand their social network to generate income and wealth, to make them self reliant, economically stable that helps to engender female sovereignty and solidarity. Educating women, providing them training and opportunities for employment and self-employment all has an added advantage of improving their familial role, enhancing their economic status and contributes towards the social well being and overall development of the nation. The socio economic development of a nation can be made rapid and holistic only when both men and women are able to contribute towards its growth and they are provided with equitable opportunities for a balanced development. The present study is based on a SHG in Kerala which emphasises on women empowerment through community based programme to eradicate poverty and bring rural women to the forefront for their upliftment in economic arena. Hence the study titled 'Kudumbashree as a Catalyst for Economic Empowerment of Rural Women through Self Help Groups in Kerala'.

\section{Review of Literature: Empirical and Conceptual}

Umashankar (2006) [2] explored the impact of participation in SHGs on the empowerment of women through concentrating on group approach programmes for rural women. Various dimensions like material, cognitive, perceptual, relational etc were focused upon. In the study it was found that, access to credit helps in the expansion of material base of women by enabling them to start and expand small businesses that often helps in wider market access. Women also experience a power within through feelings of freedom, strength, self identity and increases in levels of confidence and self-esteem. However, gender discrimination do exists in the family that is evident in the gender based division of work, roles and responsibilities as well as the mind-set towards domestic violence and issues of ownership and inheritance of land. At the social level, involvement in SHGs has enabled women to have a voice in the community affairs and helps them to tackle problems of the society. Though women face difficulties in involvement in politics, their participation in SHGs has altered them enough to become prospective leaders in the local political field. Some of the recommendations for improvement of women's conditions include providing convergence of inputs, ensure a proactive involvement of women in the program, bring changes in the social norms and perceptions and anchoring with wider movements of social change.

Dhanya and Sivakumar (2010) [3] in their paper examine the economic impact of micro finance beneficiaries. They studied whether the economic empowerment has resulted in the generation of a set of self reliant women. A case study was conducted in Thiruvananthapuram district of Kerala and the survey shows a positive impact of the development programme of Kudumbashree in Kerala. The dimension studied include women's motivation, aspiration, overcoming the fear of authority, confidence in one's own abilities, autonomy in the use of resources in households and participation in decision making in the households. It was found that weekly meeting of SHG's is not regular in some cases, so steps should be taken to conduct it regularly. Besides proper selection of activist for the group is crucial for its survival and expansion, efforts should be made to identify the suitable activity based on resources, skills and markets.

Sathiabama (2010) [4] identified that the members of SHGs are involved in Micro Entrepreneurships that have paved the way for economic development and independence of rural women. This article primarily deals with empowerment of women through entrepreneurial development activities especially among the women in rural areas. The study tries to bring to the attention that economic empowerment of women leads to development of family and community at large. This is reflected in the various success stories of collective Micro Entrepreneurship in the state of Tamil Nadu. Women entrepreneurial networks are major sources of knowledge and skill for women entrepreneurship and they are increasingly recognised as a valuable tool for its development and promotion. This network helps in providing formal and informal education and training and imparts technical knowledge in production, processing, procurement, management and marketing among the other women. This will even motivate other rural women to engage in micro entrepreneurship with the right assistance and they can strengthen their capacities besides adding to the family income and national productivity.

Chaudhary and Chani (2012) [5] in their empirical study done in Pakistan investigated on how the economic as well as the overall empowerment of women can be attained by creating consciousness or sensitising them about their rights and duties. Three major approaches to empowerment of women were looked into i.e., Integrated Development Approach, Conscious Raising Approach and Economic Empowerment Approach, by using three different and independent models. Findings reveal that as measured by Gender Empowerment Measure (GEM) index, consciousness of women about their rights, economic empowerment of women and women's overall development have positive and significant effect on women's empowerment. 
Granger Causality Test was used for testing the variables and it confirms the existence of bi-directional causality between women's overall development and women's empowerment. A unidirectional causality exists between sensitisation of women and women's empowerment and also between female labour force participation and women's empowerment. It was concluded that women empowerment can be attained by making women conscious of their rights through the provision of education and make them economically empowered through labour force participation. Above all by focusing on integrated development of women it enables them to attain the goal of overall empowerment.

Das (2012) [6] the study attempts to explore about the role of SHG as a financial intermediary for enhancing women empowerment, as micro finance is emerging as a powerful tool for poverty eradication and gender empowerment in the economy. SHG-Bank Linkage Programmes are leading to women empowerment because they have been successful in meeting financial needs of the poor rural women which helps them to strengthen the financial capacities of the poor. The empirical findings of the study conducted in Assam suggest that the micro finance programme has a substantial influence on the economic status, decision making power, knowledge \& self worthiness of women participants of SHG-Bank linkage programme. Demographic factors like age and education are not having any influence on empowerment as well as on managerial skill development among rural women. Further, appreciable changes are seen in the confidence, courage, skill development and self worthiness in rural areas, particularly among women. There is only a moderate level effect of SHG on communication, organising, competency, technical, marketing and entrepreneurial skills. Finally, there is a significant improvement of managerial skills, psychological well being and social empowerment among rural women as a result of participating in micro finance through SHGs-Bank linkage programme.

Minimol and Makesh (2012) [7] the study undertaken critically evaluates the nature and extent of impact of participation in SHGs on rural women. Detailed analysis was conducted on the extent of various levels of empowerment i.e., personal, social, economic and financial empowerment achieved by the members through their participation in SHGs. It was found that SHGs act as a resource centre for empowering women members, percolating the benefits to the society in general, it can come to a point where it becomes their choice whether to remain personally, economically and socially impoverished. It helps women to organise themselves into groups and undertake community based programmes to eradicate their deprivations. Women empowerment was not the sole motive rather, the objectives are to bring prosperity to overall family, community and to ensure social development.

Kant and Ashvine (2013) [8] in their paper attempts to study the participation of women in rural employment through MNREGA in various states of India and also in districts of Uttar Pradesh. The study analysed that there was commendable improvements in the employment opportunities generated and that most of the states and union territories have employed more than one third of women as work force resulting in women employment. The highest employment generation was amongst women in Kerala in terms of person day's employment. When we consider the total employment status of Uttar Pradesh through MNREGA, a total of 26,68,27,811 person day's employment is generated, out of which the share of women stands at 16.97 percent. They concluded that MNREGA is a programme that has impacted the lives of rural women in real sense, and has brought economic independence among women.

\subsection{Women Empowerment and Self Help Groups (SHGs)}

The SHGs is an effective medium for community involvement that infuses certain synergy among its members to move up in the socio-economic ladder from a passive onlooker to an active stakeholder in the development process. SHGs have served the cause of women empowerment, social solidarity and socioeconomic betterment of the poor in their own setting. Rani (1999) [9] evaluated the performance of the SHGs in Medak district of Andhra Pradesh and observed that the SHGs have become one of the largest and highly accepted means of effective delivery mechanism in the world. It is one of important factors determining empowerment and promotes collective action that paves the way for transparency and accountability. The provision of skill, financial services and products delivered to the poor through the SHGs, have contributed to rural development. The programme has a strong gender bias as more than 85 percent are women. The collective actions through the group have not only contributed to women empowerment but also increased their participation in the economic activities and decision making both at the household as well as at the society level. Mukerjee (2006) [10] reported that SHGs have positive impact on economic, political, household decision making and awareness level of the members with respect to social and health issues. According to (Jain, 2003) [11], the SHG is an effective medium for inculcating saving habit among poor women flock. The SHGs improve the equality of the status of women as participants and also empower their economic, social and cultural orientation in the society. Women in SHGs have the power in translating their welfare in to the welfare of their families. With the strong backing of women SHGs and local government a unique poverty alleviation programme called Kudumbashree was initiated in Kerala. 


\subsection{Kudumbashree and Women Empowerment}

Kudumbashree (KDMS) is an innovative anti-poverty programme launched on 17, May 1998, by the State Government of Kerala with the active support of the Government of India, NABARD, women SHGs and the Local Self Governments (LSGs). 'Kudumbashree' in local language means 'prosperity of the family', which helps to enjoy the economic opportunities by a good number of the poor women folks in rural and urban Kerala. It is one of the largest women's movement in Asia having over 37 lakh members and covers more than 50 per cent of households in Kerala. It envisages prosperity of the poor families in the state with multiple programmes that will provide them information, create awareness, build up their capability and capacity, enhance their confidence and show them opportunity for better social security and empower them physically, socially, economically and politically. Nidheesh (2009) [12] analysed whether membership in "Kudumbashree" leads to more equitable gender relations and economic advancement in rural area. It revealed that women empowerment is the best strategy for poverty eradication. Rural women, who were regarded as voiceless and powerless started identifying their inner strength, opportunities for growth and their role in reshaping their own destiny. The process of empowerment becomes the signal light to their children, families and the society at large.

\subsection{Economic Empowerment of Women through Kudumbashree}

KDMS functions as a catalyst for women empowerment, at multiple levels which includes economic, social and political empowerment. Various key aspects are included in the study of economic empowerment through KDMS, it includes components like personal and family income after joining KDMS, the number of micro enterprises and self employment opportunities through KDMS project, support to daily wage labourers through membership in KDMS, ability to own assets or property after becoming members of KDMS, basic facilities and household utilities of women in KDMS, position of savings and lending capacity of members and ability of repayment of loans or debt of KDMS members. The present study focused on the demographic factors (age, marital status, educational level and occupation) and their effect on the various parameters of economic empowerment of KDMS members in Malappuram district of Kerala.

\section{Objectives and Hypotheses of the Study}

\subsection{Objectives of the Study}

1. To examine the Demographic Profile of the KDMS members

2. To identify the effect of the various Demographic variables on Economic Empowerment of KDMS members for the samples based on age, marital status, education level and occupation

3. To find the effect of Education Level on various parameters of Economic Empowerment

4. To find the effect of Occupation on various parameters of Economic Empowerment

\subsection{Hypotheses}

1. $\mathbf{H}_{\mathbf{0 1}}$ : There is no significant difference in the mean value of Economic Empowerment of KDMS members across age, marital status, education level and occupation.

2. $\mathbf{H}_{\mathbf{0 2}}$ : There is no significant difference in the mean value of parameters of Economic Empowerment of KDMS members based on education level.

3. $\mathbf{H}_{\mathbf{0} 3}$ : There is no significant difference in the mean value of parameters of Economic Empowerment of KDMS members based on occupation.

\section{Research Methodology}

The research was exploratory and descriptive in nature. The three tier systems of KDMS consisting of Neighbourhood Groups (NHGs), Area Development Societies (ADSs) and Community Development Societies (CDSs) in Malappuram district of Kerala were selected for studying the nature and economic empowerment of women. Sample size consisting of 150 women from various NHGs of the district was considered. Primary data was collected through interviews and meetings with different categories of members of KDMS. Various types of secondary data including studies, reports and data collected by government and non-governmental organisations were used for the study. Data and information were collected by employing a structured interview schedule. Five point rating scale to assess Economic Empowerment of Women in KDMS was used and it consisted of ratings 5, 4, 3, 2, and 1 for Highly Increased, Increased, Moderate, Decreased, and Highly Decreased respectively. The data analysis was done by using the SPSS software by applying one way ANOVA as the main statistical technique.

\section{Results and Discussions}


Table 1: examines the demographic profile of KDMS members selected as samples from the district of Malappuram. Simple percentage analysis was used to check the percentage of sample belonging to various categories like age, marital status, educational level and occupation. The demographic profile of NHG members selected as sample given in the table clearly indicates that $52.7 \%$ of the members are between age group of 3145 years, $27.3 \%$ are from the age group between $18-30$ years and only $20 \%$ comes under the age group of 46 years and above. Majority i.e., 53.4\% of members are married, $25.3 \%$ unmarried and the rest were either widows or divorced women. It also reveals that $34 \%$ of the respondents have secondary education, $23.3 \%$ of the respondents are educated upto primary level and the rest $30 \%$ and $12.7 \%$ have higher secondary and higher education respectively. The occupational status of respondents shows that the private employed, women entrepreneurs, daily wage labourers and other self employed were $13.3 \%, 30 \%, 37.3 \%$ and $19.3 \%$ respectively.

TABLE: 1

Demographic Profile of NHG Members Selected as Sample

\begin{tabular}{|c|c|c|c|}
\hline Sl. No & Characteristics & No. of Respondents & $\%$ to Total \\
\hline \multirow[t]{4}{*}{ I } & Age & & \\
\hline & 18-30 Years & 41 & 27.3 \\
\hline & $31-45$ Years & 79 & 52.7 \\
\hline & 46 and Above & 30 & 20.0 \\
\hline \multirow[t]{4}{*}{ II } & Marital Status & & \\
\hline & Single & 38 & 25.3 \\
\hline & Married & 80 & 53.4 \\
\hline & Others & 32 & 21.3 \\
\hline \multirow[t]{5}{*}{ II } & Education Level & & \\
\hline & Primary & 35 & 23.3 \\
\hline & Secondary & 51 & 34.0 \\
\hline & Higher Secondary & 45 & 30.0 \\
\hline & Higher Education & 19 & 12.7 \\
\hline \multirow[t]{5}{*}{ III } & Occupation & & \\
\hline & Private Employed & 20 & 13.3 \\
\hline & Women Entrepreneur & 45 & 30.0 \\
\hline & Daily Wage Labourer & 56 & 37.3 \\
\hline & Other Self Employment & 29 & 19.3 \\
\hline
\end{tabular}

Source: Field Survey

Table 2: represent the mean value and standard deviation of Economic Empowerment achieved on the basis of age by the KDMS members. It has been found from the above table that the age group between ' $31-45$ ' and 46 and Above are having high mean scores of 3.16 and 3.08 respectively on five point scale and a standard deviation of 0.514 and 0.669 respectively. It clearly indicates that these KDMS members have achieved more economic empowerment when compared to other categories based on agewise grouping.

TABLE: 2

ANOVA Test for Variance of Means: Economic Empowerment with Age

\begin{tabular}{|c|c|c|c|c|c|c|c|}
\hline \multirow{4}{*}{ Age Group } & Categories & $\mathbf{N}$ & Mean & $\begin{array}{l}\text { Standard } \\
\text { Deviation }\end{array}$ & $\mathbf{F}$ & Sig. & $\begin{array}{c}\text { H}_{0} \\
\text { Accepted/ } \\
\text { Rejected }\end{array}$ \\
\hline & $18-30$ & 41 & 3.031 & 0.510 & \multirow{3}{*}{0.726} & \multirow{3}{*}{0.486} & \multirow{3}{*}{ Accepted } \\
\hline & $31-45$ & 79 & 3.156 & 0.514 & & & \\
\hline & 46 and Above & 30 & 3.086 & 0.669 & & & \\
\hline
\end{tabular}

Source: SPSS Results

*Denotes Significant Variance of Means at $95 \%$ Confidence Level

ANOVA was performed to test the differences if any in the economic empowerment of KDMS members on the basis of the various demographic variables. The ' $F$ ' value for economic empowerment based on the demographic factor age was 0.726 . The significant value $(\mathrm{P})$ was 0.486 . Since the significance values in this case is greater than 0.05 ( $95 \%$ confidence interval) ANOVA proves no statistical significance $\left(\mathrm{H}_{0}\right.$ is accepted) in the inter group differences between the age and economic empowerment. 
TABLE: 3

ANOVA Test for Variance of Means: Economic Empowerment with Marital Status

\begin{tabular}{|c|c|c|c|c|c|c|c|}
\hline \multirow{4}{*}{ Marital Status } & Categories & $\mathbf{N}$ & Mean & $\begin{array}{l}\text { Standard } \\
\text { Deviation }\end{array}$ & F & Sig. & $\begin{array}{c}\mathbf{H}_{0} \\
\text { Accepted/ } \\
\text { Rejected }\end{array}$ \\
\hline & Single & 38 & 3.350 & 0.553 & \multirow{3}{*}{5.546} & \multirow{3}{*}{$0.005^{*}$} & \multirow{3}{*}{ Rejected } \\
\hline & Married & 80 & 3.003 & 0.511 & & & \\
\hline & Others & 32 & 3.080 & 0.549 & & & \\
\hline
\end{tabular}

Source: SPSS Results

*Denotes Significant Variance of Means at $95 \%$ Confidence Level

The above Table 3: analyses the effect of independent variable marital status on the dependent variable economic empowerment. The mean value and standard deviation of Economic Empowerment achieved on the basis of marital status by the KDMS members reveals that unmarried women have a high mean score value of 3.35 and a standard deviation of 0.55 . It shows that the unmarried women in the selected sample are showing a greater effect on economic empowerment than the others.

ANOVA was performed to test the differences if any in the economic empowerment of KDMS members on the basis of marital status. The ' $F$ ' value for economic empowerment based on marital status was 5.546. The significant value $(\mathrm{P})$ was 0.005 . Since the significance value is less than $0.05 \mathrm{H}_{0}$ is rejected. ANOVA proves a statistical significance in the inter group differences between marital status and economic empowerment.

TABLE: 4

ANOVA Test for Variance of Means: Economic Empowerment with Education Level

\begin{tabular}{|c|c|c|c|c|c|c|c|}
\hline \multirow{5}{*}{ Education Level } & Categories & $\mathbf{N}$ & Mean & $\begin{array}{l}\text { Standard } \\
\text { Deviation }\end{array}$ & $\mathbf{F}$ & Sig. & $\begin{array}{c}\mathbf{H}_{0} \\
\text { Accepted// } \\
\text { Rejected }\end{array}$ \\
\hline & Primary & 35 & 2.612 & 0.552 & \multirow{4}{*}{17.07} & \multirow{4}{*}{$0.000 *$} & \multirow{4}{*}{ Rejected } \\
\hline & Secondary & 51 & 3.199 & 0.437 & & & \\
\hline & Higher Secondary & 45 & 3.311 & 0.487 & & & \\
\hline & Higher Education & 19 & 3.293 & 0.376 & & & \\
\hline
\end{tabular}

Source: SPSS Results

*Denotes Significant Variance of Means at $95 \%$ Confidence Level

Table 4: reveals the effect of education level on the economic empowerment of KDMS members. It is evident that the mean value of the categories 'higher secondary' and 'higher education' is highest with scores of 3.31 and 3.29 respectively indicating that the higher education and higher secondary level educated members have a greater effect on the economic empowerment through KDMS.

ANOVA to test the differences if any in the economic empowerment of KDMS members on the basis of education level shows an ' $F$ ' value of 17.07. The significant value $(P)$ was 0.000 . The significance value is less than 0.05 therefore, the $\mathrm{H}_{0}$ is rejected, which shows that there is a significant difference in the inter group differences between educational level of various members and the economic empowerment.

Table 5: represent the mean value and standard deviation of Economic Empowerment achieved on the basis of occupation by the KDMS members. It is clear from the above table that the daily wage labourers and other self employed members of KDMS have the highest mean value of 3.20 and 3.31 respectively on five point scale. It indicates that these KDMS members have greater effect on economic empowerment when compared to other categories in the same group.

ANOVA to test the differences if any in the economic empowerment of KDMS members on the basis of occupation reveals that the ' $F$ ' values for economic empowerment across occupation was 3.976. The significant value $(\mathrm{P})$ was 0.009 it is less than 0.05 which shows that the inter group difference was significant as the $\mathrm{H}_{0}$ is rejected.

TABLE: 5

ANOVA Test for Variance of Means: Economic Empowerment with Occupation

\begin{tabular}{|c|l|c|c|c|c|c|c|}
\hline \multirow{3}{*}{ Occupation } & \multicolumn{1}{|c|}{ Categories } & N & Mean & $\begin{array}{c}\text { Standard } \\
\text { Deviation }\end{array}$ & F & Sig. & $\begin{array}{c}\mathbf{H}_{\mathbf{0}} \\
\text { Accepted/ } \\
\text { Rejected }\end{array}$ \\
\cline { 2 - 9 } & Private Employed & 20 & 2.921 & 0.460 & 3.976 & $0.009 *$ & Rejected \\
\cline { 2 - 9 } & Women Entrepreneur & 45 & 2.952 & 0.577 & \multirow{2}{*}{ Rejed } \\
\hline
\end{tabular}




\begin{tabular}{|l|l|l|l|l|l|l|}
\hline & Daily Wage & 56 & 3.196 & 0.563 & & \\
\cline { 2 - 5 } & Other Self Employment & 29 & 3.305 & 0.421 & & \\
\hline
\end{tabular}

Source: SPSS Results

*Denotes Significant Variance of Means at $95 \%$ Confidence Level

Since the significance values in all the cases except agewise comparison of economic empowerment were less than $0.05(95 \%$ confidence interval) ANOVA proves that there is a statistically significant difference in the inter group comparison between the various categories on economic empowerment. Hence the $\mathrm{H}_{0}$ (null hypothesis) that there is no significant variation in the mean value of Economic Empowerment of KDMS members for the samples based on marital status, educational level and occupation is rejected and alternative hypothesis is accepted. However in the case of effect of age on economic empowerment the study reveals that there is no significant difference between the variables therefore the null hypothesis is accepted and alternative hypothesis stands rejected.

Table 6: examines the effect of Educational Levels on Economic Empowerment variables like personal and family income after joining KDMS, the number of micro enterprises and self employment opportunities through KDMS project, support to daily wage labourers through membership in KDMS, ability to own assets or property after becoming members of KDMS, basic facilities and household utilities of women in KDMS, position of savings and lending capacity of members and ability of repayment of loans or debt of KDMS were analysed for differences. ANOVA test for variance of means of economic empowerment parameters with educational level shows that there is a statistical significance (significance $<0.05$ ) in all the case except in the case of 'Ability of repayment of loans or debt of KDMS members'. ANOVA results reveal that economic empowerment was statistically significant with the Sig. value (P) less than 0.05 in almost all the cases. Therefore the $\mathrm{H}_{0}$ is rejected showing a statistical significance in the economic parameters of empowerment in relation to education level in all the parameters except with regard to 'ability of repayment of loans or debt of KDMS members'.

TABLE: 6

ANOVA Test for Variance of Means:

Economic Empowerment Parameters with Education Level

\begin{tabular}{|c|c|c|c|c|c|c|c|}
\hline $\begin{array}{l}\text { SI } \\
\text { No }\end{array}$ & Parameters of Economic Empowerment & Education & $\mathbf{N}$ & Mean & $\mathbf{F}$ & Sig. & $\begin{array}{c}\mathbf{H}_{0} \\
\text { Accept/ } \\
\text { Reject }\end{array}$ \\
\hline \multirow[t]{4}{*}{1} & \multirow{4}{*}{$\begin{array}{l}\text { Personal and family income after joining } \\
\text { KDMS }\end{array}$} & Primary & 35 & 2.40 & \multirow{4}{*}{6.58} & \multirow{4}{*}{$0.000 *$} & \multirow{4}{*}{ Reject } \\
\hline & & Secondary & 51 & 3.22 & & & \\
\hline & & Higher Secondary & 45 & 3.22 & & & \\
\hline & & Higher Education & 19 & 3.42 & & & \\
\hline \multirow[t]{4}{*}{2} & \multirow{4}{*}{$\begin{array}{l}\text { The number of micro enterprises and self } \\
\text { employment opportunities through KDMS } \\
\text { project }\end{array}$} & Primary & 35 & 2.49 & \multirow{4}{*}{6.391} & \multirow{4}{*}{$0.000 *$} & \multirow{4}{*}{ Reject } \\
\hline & & Secondary & 51 & 3.35 & & & \\
\hline & & Higher Secondary & 45 & 3.40 & & & \\
\hline & & Higher Education & 19 & 3.37 & & & \\
\hline \multirow[t]{4}{*}{3} & \multirow{4}{*}{$\begin{array}{l}\text { Support to daily wage labourers through } \\
\text { membership in KDMS }\end{array}$} & Primary & 35 & 2.63 & \multirow{4}{*}{7.143} & \multirow{4}{*}{$0.000 *$} & \multirow{4}{*}{ Reject } \\
\hline & & Secondary & 51 & 3.24 & & & \\
\hline & & Higher Secondary & 45 & 3.60 & & & \\
\hline & & Higher Education & 19 & 3.26 & & & \\
\hline \multirow[t]{4}{*}{4} & \multirow{4}{*}{$\begin{array}{l}\text { Ability to own assets or property after } \\
\text { becoming members of KDMS }\end{array}$} & Primary & 35 & 2.63 & \multirow{4}{*}{3.108} & \multirow{4}{*}{$0.028 *$} & \multirow{4}{*}{ Reject } \\
\hline & & Secondary & 51 & 3.20 & & & \\
\hline & & Higher Secondary & 45 & 3.18 & & & \\
\hline & & Higher Education & 19 & 3.16 & & & \\
\hline \multirow[t]{4}{*}{5} & \multirow{4}{*}{$\begin{array}{l}\text { Basic facilities and household utilities of } \\
\text { women in KDMS }\end{array}$} & Primary & 35 & 2.71 & \multirow{4}{*}{3.915} & \multirow{4}{*}{$0.010 *$} & \multirow{4}{*}{ Reject } \\
\hline & & Secondary & 51 & 3.14 & & & \\
\hline & & Higher Secondary & 45 & 3.22 & & & \\
\hline & & Higher Education & 19 & 3.63 & & & \\
\hline \multirow[t]{4}{*}{6} & \multirow{4}{*}{$\begin{array}{l}\text { Position of savings and lending capacity of } \\
\text { members }\end{array}$} & Primary & 35 & 2.60 & \multirow{4}{*}{4.743} & \multirow{4}{*}{$0.003 *$} & \multirow{4}{*}{ Reject } \\
\hline & & Secondary & 51 & 2.96 & & & \\
\hline & & Higher Secondary & 45 & 3.31 & & & \\
\hline & & Higher Education & 19 & 2.79 & & & \\
\hline \multirow[t]{4}{*}{7} & & Primary & 35 & 2.83 & & & \\
\hline & Ability of repayment of loans or debt of & Secondary & 51 & 3.29 & 2503 & 0062 & Accent \\
\hline & KDMS members & Higher Secondary & 45 & 3.22 & 2.503 & 0.062 & Accept \\
\hline & & Higher Education & 19 & 3.42 & & & \\
\hline
\end{tabular}

Source: SPSS Results

*Denotes Significant Variance of Means at $95 \%$ Confidence Level 
Economic empowerment variables were also analysed for revealing the effect of Occupation of members in achieving economic empowerment Table 7: reveals the ANOVA Test for Variance of Means for Economic Empowerment Parameters with Occupation were statistically not significant in most of the parameters except in the case of the parameter 'number of micro enterprises and self employment opportunities through KDMS project'. This parameter has a Sig. value of 0.000 which is less than 0.05 , which indicates that the null hypothesis is rejected and there is a statistically significant variation. While all other economic parameters studied with occupation has a Sig. value more than 0.05 showing that there exists no significant variation in different occupation on the various economic empowerment parameters.

TABLE: 7

ANOVA Test for Variance of Means: Economic Empowerment Parameters with Occupation

\begin{tabular}{|c|c|c|c|c|c|c|c|}
\hline $\begin{array}{l}\text { Sl } \\
\text { No }\end{array}$ & $\begin{array}{c}\text { Parameters of Economic } \\
\text { Empowerment }\end{array}$ & Occupation & $\mathbf{N}$ & Mean & $\mathbf{F}$ & Sig. & $\begin{array}{c}\mathbf{H}_{0} \\
\text { Accept/ } \\
\text { Reject }\end{array}$ \\
\hline \multirow[t]{4}{*}{1} & \multirow{4}{*}{$\begin{array}{l}\text { Personal and family income } \\
\text { after joining KDMS }\end{array}$} & Private Employed & 20 & 2.80 & \multirow{4}{*}{1.605} & \multirow{4}{*}{0.191} & \multirow{4}{*}{ Accept } \\
\hline & & Women Entrepreneur & 45 & 2.87 & & & \\
\hline & & Daily Wage & 56 & 3.16 & & & \\
\hline & & Other Self Employment & 29 & 3.31 & & & \\
\hline \multirow[t]{4}{*}{2} & \multirow{4}{*}{$\begin{array}{l}\text { The number of micro } \\
\text { enterprises and self } \\
\text { employment opportunities } \\
\text { through KDMS project }\end{array}$} & Private Employed & 20 & 2.85 & \multirow{4}{*}{3.830} & \multirow{4}{*}{$0.011 *$} & \multirow{4}{*}{ Reject } \\
\hline & & Women Entrepreneur & 45 & 2.82 & & & \\
\hline & & Daily Wage & 56 & 3.38 & & & \\
\hline & & Other Self Employment & 29 & 3.52 & & & \\
\hline \multirow[t]{4}{*}{3} & \multirow{4}{*}{$\begin{array}{l}\text { Support to daily wage } \\
\text { labourers through } \\
\text { membership in KDMS }\end{array}$} & Private Employed & 20 & 2.95 & \multirow{4}{*}{1.619} & \multirow{4}{*}{0.187} & \multirow{4}{*}{ Accept } \\
\hline & & Women Entrepreneur & 45 & 3.04 & & & \\
\hline & & Daily Wage & 56 & 3.30 & & & \\
\hline & & Other Self Employment & 29 & 3.45 & & & \\
\hline \multirow[t]{4}{*}{4} & \multirow{4}{*}{$\begin{array}{l}\text { Ability to own assets or } \\
\text { property after becoming } \\
\text { members of KDMS }\end{array}$} & Private Employed & 20 & 2.70 & \multirow{4}{*}{1.876} & \multirow{4}{*}{0.136} & \multirow{4}{*}{ Accept } \\
\hline & & Women Entrepreneur & 45 & 3.00 & & & \\
\hline & & Daily Wage & 56 & 3.07 & & & \\
\hline & & Other Self Employment & 29 & 3.34 & & & \\
\hline \multirow[t]{4}{*}{5} & \multirow{4}{*}{$\begin{array}{l}\text { Basic facilities and } \\
\text { household utilities of women } \\
\text { in KDMS }\end{array}$} & Private Employed & 20 & 2.80 & \multirow{4}{*}{1.370} & \multirow{4}{*}{0.254} & \multirow{4}{*}{ Accept } \\
\hline & & Women Entrepreneur & 45 & 3.02 & & & \\
\hline & & Daily Wage & 56 & 3.25 & & & \\
\hline & & Other Self Employment & 29 & 3.28 & & & \\
\hline \multirow[t]{4}{*}{6} & \multirow{4}{*}{$\begin{array}{l}\text { Position of savings and } \\
\text { lending capacity of members }\end{array}$} & Private Employed & 20 & 3.05 & \multirow{4}{*}{0.693} & \multirow{4}{*}{0.558} & \multirow{4}{*}{ Accept } \\
\hline & & Women Entrepreneur & 45 & 2.80 & & & \\
\hline & & Daily Wage & 56 & 3.04 & & & \\
\hline & & Other Self Employment & 29 & 3.00 & & & \\
\hline \multirow[t]{4}{*}{7} & & Private Employed & 20 & 3.30 & & & \\
\hline & Ability of repayment of & Women Entrepreneur & 45 & 3.11 & 0245 & 0965 & $\Delta$ \\
\hline & $\begin{array}{l}\text { loans or debt of KDIMS } \\
\text { members }\end{array}$ & Daily Wage & 56 & 3.16 & 0.245 & 0.865 & Accept \\
\hline & & Other Self Employment & 29 & 3.24 & & & \\
\hline
\end{tabular}

Source: SPSS Results

*Denotes Significant Variance of Means at $95 \%$ Confidence Level

\section{Conclusion}

The foregoing discussion revealed that Kudumbashree is regarded as the major agent of change by participating women in various income generating-cum developmental activities, the morale and confidence of women has also become very high. Women empowerment is not characterised as achieving power of women to dominate others, but rather power to act with others to affect change. The women's movement and a widespread network of NGOs which have strong grass-roots presence and deep insight into women's concerns have contributed in inspiring initiatives for the empowerment of women. The formation of self-help groups as a basis for social and economic empowerment of deprived and disadvantaged women have been found to be successful mechanism for the organisation, mobilisation and self-development of women. Women who have participated in self-help or neighbourhood groups have developed strong sense of self worth and faith in their ability to interact with power structures and increase in their contribution to the household. The study clearly indicates that the NHGs movement of Kudumbashree is significantly supporting women empowerment. Findings of the study reveals that majority of the members in KDMS are between the age group of 31-45 years having secondary education belonging to daily wage labourer category. It was found that there is economic empowerment among the members with respect to certain demographic variables. Statistical significance in the inter group differences between the various categories of demographic variables and economic empowerment in general and with respect to certain specific economic parameters were also identified. KDMS thus function as a catalyst for economic empowerment of women by building up women's capacity to become economically self-reliant and 
self-sufficient, acquire the ability to make better decisions in their family, improve their familial and societal status and enjoy a better standard of living.

\section{References}

[1] Murugan, K.R. \& Dharmalingam, B. (2000). Self Help Groups- New Women's Movement in Tamil Nadu. Social Welfare, 47(80):9-12.

[2] Umashankar, D. (2006), Women's Empowerment: Effect of Participation in Self Help Groups. Unpublished Dissertation of Indian Institute of Management (IIM), Bangalore. Retrieved from: http://www.iimb.ernet.in/microfinance/Docs/Students/women\%20empower\%20Deepti.pdf.

[3] Dhanya, M.B \& Sivakumar, P. (2010), Women Empowerment and Micro Finance: Case Study from Kerala. MPRA Paper No.25337. Retrieved from: http://mpra.ub.uni-muenchen.de/25337/1/MPRA_paper_25337.pdf.

[4] Sathiabama, K. (2010), Rural Women Empowerment and Entrepreneurship Development , (No. id: 2475) ESS Student Papers.

[5] Chaudhary, R; Chani, M.I \& Pervaiz, Z. (2012). An Analysis of Different Approaches to Women Empowerment: A Case Study of Pakistan, World Applied Sciences Journal, 16(7), 971-980. Retrieved from: http://mpra.ub.unimuenchen.de/37784/2/MPRA paper 37784.pdf.

[6] Das, S.K. (2012), Socio-economic Empowerment of Women through SHG-Banking Linkage Programme: A Boon for Development, International Journal of Management \& Business Studies (IJMBS), 2(1), 39-46.

[7] Minimol. M, C \& Makesh, K.G (2012), Empowering Rural Women in Kerala: A Study on the Role of Self Help Groups (SHGs). International Journal of Sociology and Anthropology, 4 (9), 270-280. Retrieved from: http://www.academicjournals.org/journal/IJSA/article-full-text-pdf/DABCA945105.

[8] Kant, S.V \& Ashvine, K. (2013), Women Empowerment through Rural Employment in Uttar Pradesh, International Journal of Engineering and Management Sciences (IJEMS), 4 (2).

[9] Rani, C. (1999), "Evaluation of Self Help Groups (SHGs) in Medak District, DRDA.

[10] Mukerjee, T. (2006). Impact Assessment Study of SGSY Programme on Empowerment of Women at Babpur Village. Vidyasagar School of Social Work, 5(1).

[11] Jain, R. (2003), "Socio-Economic Impact through Self Help Groups", Yojana, 47(7), 11-12.

[12] Nidheesh, K.B. (2009). A Study on the Changing Process of Kerala Women through Kudumbashree in Kerala. International NGO Journal, $14 \quad$ (8), 352-361. Retrieved from: http://www.academicjournals.org/article/article1381500916_Nidheesh.pdf.

[13] Beteta, H.C. (2006). 'What is missing in Measures of Women's Empowerment?' Journal of Human Development, 7(2), 221-241.

[14] Chattopadhyay, R \& Duflo, E. (2004), Women as Policy Makers: Evidence from a Randomized Policy Experiment in India, Econometrica 72(5), 1409-1443.

[15] Desai, M. (2010), Hope in Hard Times: Women's Empowerment and Human Development, Human Development Research Paper. United Nations Development Programme Human Development Reports Research Paper.

[16] Dijkstra, G. (2002). 'Revisiting UNDP's GDI and GEM: Towards an Alternative', Social Indicators Research, Vol. 57, 301-338.

[17] Johnson, S. (2005). 'Gender Relations, Empowerment and Microcredit: Moving on from a Lost Decade', The European Journal of Development Research, 17(2), 224-248.

[18] Mayoux, L. (2000): Micro-Finance and the Empowerment of Women - A Review of the Key Issues, Working Paper.

[19] Siva Prakash, C.S \& Chandarsekar, K.S. (2012) SHGs and Socio-Economic Empowerment: A Descriptive Analysis Based on Kudumbashree Project in Kerala, University of Kerala. International Journal of Business and Management Tomorrow, 2 (2), 1-10.

[20] Swain, R.B \& Varghese, A. (2009), Does Self Help Group Participation Lead to Asset Creation? World Development, 37(10), 1674-1682.

[21] Shihabudheen, N. (2012), Role of Micro Enterprises in Women Empowerment: Evidence from a Field Study of Kudumbashree"e Units in Ernakulam District in Kerala, IOSR Journal of Humanities and Social Science (JHSS), 3(6), 06-12.

[22] Stotsky, J. G. (2006): Gender and its Relevance to Macroeconomic Policy: A Survey. IMF Working Paper no. $\mathrm{WP} / 06 / 233$.

[23] Bardhan, K. \& Klasen, S. (1999). 'UNDP's Gender-related Indices: a Critical Review', World Development, 27, 985-1010. 